UDK 528.946

\title{
IDENTIFYING ACTIVE FIRE IN SOUTHWESTERN NIGERIA WITH MODIS DATA AND GEOGRAPHICAL INFORMATION SYSTEMS
}

\author{
Ebenezer Yemi OGUNBADEWA \\ Remote sensing/GIS Unit, Geography Department, \\ Adekunle Ajasin University, \\ Akungba-Akoko, Ondo-State, Nigeria \\ E-mail: ogunbadewa202@yahoo.com
}

Received 07 March 2015; accepted 20 May 2015

\begin{abstract}
The potentials of active fire product derived from Moderate Resolution Imaging Spectroradiometer (MODIS) sensor on board of Terra and Aqua spacecrafts were examined for fire detection in a variety of ecosystems in the south western Nigeria. Fire information were obtained from the archived time series MODIS active fire datasets for 10 years (January 2002 to December 2011) and was superimposed on the map of ecosystem types (Intensively cultivated farmlands, woodlands, highland forest, freshwater swamp forest, tree crop plantation, forest plantation, mangrove forest and forest reserves) of the study area. MODIS active fire data were used to investigate the annual trends, geographical spread of fire occurrence and Principal Component Analysis (PCA) was used to identify the degree of fire events in each of ecosystems. The results show that MODIS active fire data imported into the Geographical Information Systems (GIS) data format and analyzed with PCA revealed that highland forest, forest plantation and intensively cultivated farmlands were heavily loaded on the first principal component and accounted for $87.56 \%$ variance in the original data. The second principal component accounting for $4.72 \%$ is heavily loaded with freshwater swamp forest, forest reserves and tree crop plantation while the regression coefficient of the component score matrix of the first principal component related to the original variables distinguished intensively cultivated farmlands and highland forest as the major source of ecosystems fire in the study area. It is concluded that MODIS active fire data together with PCA can provide a well coordinated near real time information that will be valuable for early warning, monitoring, mitigation and intervention against active fire disaster and catastrophic biomass burning plus a supportive guide for post fire assessment and recovery.
\end{abstract}

Keywords: satellite, GIS, optical systems, fire, ecosystem.

\section{Introduction}

Fire associated with biomass burning in ecosystems has long been utilized in agricultural practices in south western Nigeria. For example, in the clearing of arable lands, controlling insects and pests, regenerating of pastures, removing wastes from farmlands, soil fertilisation, hunting and beekeeping (Raish, GonzálezCabán et al. 2005; Haywood, Pelon et al. 2008; Montiel and Kraus 2010; d'Oliveira, Alvarado et al. 2011). However, in Nigeria the use of fire in agricultural activities has been a major policy concern due to the fact that frequent calamitous wildfire originates from the uncontrolled utilization with concomitant negative impacts on the environment and socio-economic systems. This has led to pervasive deforestation, severe droughts, dysfunction of the ecosystem, destruction of biodiversity, disturbance of soil microbiology, aggravation of soil erosion, degradation of grazing lands, air pollution and loss of wildlife, human life and property. In addition, the gases, heat, smoke, dust and aerosol particles emanating from the pyrogenic processes of fire are known to be precursors to global warming, climate change and micro- climatic modification at a local scale, such as in the study area, due to fire activities (Changnon, Holton 2003; Langmann et al. 2009; Ramanathan, Feng 2009; Jury, Whitehall 2010; Arneth et al. 2010). Unfortunately, the unmitigated fire events has aggravated the socio-economic predicaments of 
the already vulnerable society where low level of technological development clearly shows that the existing capacity cannot cope with or proactively respond to the resultant perturbations of disastrous fire outbreak. Further more, most fire occurrence cut across administrative boundaries. Regrettably, the situation is likely to be worsened in the nearest future due to increase in the use of fire for clearing arable lands. Thus, in this type of environment, where deforestation by fire is a threat to ecosystem sustainability by biomass burning causing atmospheric upsurge in carbon emission, managing the uses of fire will require timely detection and location of possible areas of incidence as a fundamental lead to fire mitigation and carbon emission reduction programmes. In the study area, there is no quantitative and comprehensive data on the temporal and spatial information of fire incidence which is vital in mitigating impacts of fire emissions on climate. There is therefore a need for the most appropriate technique that has a measurable quantity and improved observation method that can give an insight into the nature, causes and magnitude of fire occurrence before adequate planning against catastrophic fire can be put in place. The most appropriate observation and data source, that can provide this information in near real-time and in terms of area extent is satellite remote sensing systems.

Satellite remote sensing systems offers a scientific and technological innovations into the study of incessant active fire in ecosystems because of its capability of providing data at a higher acquisition frequency in real-time for extensively large areas as well as locating hotspots, tracking spread, identifying susceptibility, assessing risks of active fire and post-fire damage at very low cost when compared with operational groundbased and air-borne detection which are hampered by financial, logistical and technological constraints in the study area (Kiran Chand et al. 2006; Dlamini 2009; Keeley 2009; Xu et al. 2010; Chuvieco et al. 2010; Devineau et al. 2010). Moreover the dangerous nature of active fire raises the concern for safety because accessibility to the areas of fire outburst is risky making observation by satellite remote systems the most suitable and significant data source as the data is remotely collected without physical contact with the data collector and environment.

The aim of this study is to identify the degree of active fire in each type of the ecosystems in the study area with remote sensing data derived from MODIS active fire product and evaluate the data obtained with Principal Component Analysis (PCA).

\section{Fire detection techniques by remote sensing systems}

There are three major techniques of fire detection by remote sensing systems. Namely; threshold, contextual and associated fire attributes techniques. The threshold methods flag temperatures higher than the normal land surface background temperatures as fire. The threshold methods are of two types; these include fixed/single threshold and multichannel threshold methods. The fixed/single channel method uses a fixed channel of mid-infrared wavelength because this portion provides a strong signal of fires with peak radiation at $3.5 \mu \mathrm{m}$ to $5 \mu \mathrm{m}$ that enables differentiation between hotspots and cold surroundings. However, the limitation of using single channel mid-infrared brightness temperature threshold is that other non-fire sources such as rock and bare ground can also induce high mid-infrared brightness temperature. Thus there is propensity of false alarm when using a single channel mid-infrared brightness temperature threshold (Justice et al. 1996; Giglio et al. 2009). Despite the low saturation level $(325 \mathrm{~K})$, fixed/single is not duly affected by interference of the peak radiations from the Earth's surface $(0.5 \mu \mathrm{m})$ and solar radiation from the sun $(9.7 \mu \mathrm{m})$ because of the far distance of mid-infrared from these wavelengths and it works well when it is calibrated with local temperature conditions. In order to minimize the rate of false fire alarms multichannel thresholds detection technique was developed by using both the temperature of mid-infrared $\left(\mathrm{T}_{\mathrm{m}}\right)$ and thermal-infrared $\left(\mathrm{T}_{t}\right)$. Pixels are classified as fire pixel when mid-infrared temperature is greater or equal to $320 \mathrm{~K}$, difference between the mid-infrared and thermal-infrared temperature is greater than $10 \mathrm{~K}$ and thermal-infrared temperature is greater than $240 \mathrm{~K}$ (Zhao et al. 2010; He, Li 2012). The assumptions of multichannel thresholds technique is given as $; \mathrm{T}_{\mathrm{m}} \geq 320 \mathrm{~K}$, difference between $T_{m-} T_{t}>10 K$ and $T_{t}>240 \mathrm{~K}$. The multichannel thresholds detection technique performs better for continental and global applications but for local and regional purposes further tests have to be carried out due to reflections from heterogeneous land surfaces and different cloud types.

The contextual methods use multichannel threshold and variable background thresholds that are pixel specific with computation of mean, median and standard deviation of threshold variable in the mid-infrared $(3.5-5 \mu \mathrm{m})$ and thermal-infrared $(8-14 \mu \mathrm{m})$ wavebands (Flasse, Ceccato 1996; Amraoui et al. 2010). In addition, it involves fine tuning at sub-pixel fire size 
and temperature to remove thermal anomaly associated with overheating/overcooling of the ground, clouds and water bodies. This method has the merits of combining both single and multichannel approach but is hampered by when the background window is highly heterogeneous and poorly characterized. Also scan angle of satellite data acquisition far away from the nadir may be a limitation resulting in inadequate sampling of the background.

The most common associated fire attributes used in detection of active fire are thermal emitted smoke plume emitted and thermal emitted radiance during fire occurrence. The visible $(0.4-0.7 \mu \mathrm{m})$ and nearinfrared (NIR: $0.7-1.1 \mu \mathrm{m}$ ) wavebands are used for this purpose. This technique compliments the other ones to reduce false alarms arising from thin clouds by differentiating fire smoke from the background (Dlamini 2009; Reid et al. 2009). This method is disadvantaged because strong wind can blow the smoke far away from where the fire originates and smoke can only emerge when fire is in progress.

\section{Satellite remote sensing of fire}

The use of satellite remote sensing systems for surveillance and detection of active fire in ecosystems are based on the above mentioned techniques. The common method employed by these satellite sensors is to explore the spectral bands that are sensitive to some fire attributes. For example, thermal and mid-infrared bands are sensitive to temperature, while the visible and near infrared bands are insightful to smoke and lightening from thunder. For example, the Advanced Very High Resolution Radiometer (AVHRR: Lentile et al. 2006; Van Der Werf et al. 2006; Pu et al. 2007), Geostationary Operational Environmental Satellite (GOES: Zhang, Kondragunta 2008), Meteosat-Spinning Enhanced Visible and Infrared Imager (SEVIRI: Roberts, Wooster 2008), Tropical Rainfall Measuring Mission (TRMM: Freitas et al. 2005), Advanced Spaceborne Thermal Emission and Reflection Radiometer (ASTER: Giglio et al. 2008), Total Ozone Mapping Spectrometer (TOMS: Zhang et al. 2005), Along Track Scanning Radiometer (ATSR: Fuller, Murphy 2006), Advanced Along Track Scanning Radiometer (AATSR: Mota et al. 2006), Defence Meteorological Satellite Programme-Operational Line-scan System (DMSP OLS: Kiran Chand et al. 2006) Landsat- Enhanced Thematic Mapper Plus (Landsat-ETM+: Silva et al. 2005), Satellite Pour IXObservation de la TerreVEGETATION (SPOT-VEGETATION: Bartalev et al.
2007), Moderate Resolution Imaging Spectroradiometer (MODIS: Giglio et al. 2006). There has been regular usage of these satellite sensors for fire detection but their capabilities are limited as they are not intended for discovery of fire. For instance, the AVHRR, GOES and SEVIRI were originally designed as meteorological satellites, TOMS and TRMM can detect forest fires but they were primarily planned to collect data on ozone levels and rainfall/lightening associated with thunder strikes respectively. DMSP OLS and ATSR/AATSR are for night time fire detection, the geostationary GOES satellites have a spatial resolution of $4 \mathrm{~km}$ with limited capability to detect small fires. High spatial resolution satellite sensors, such as Satellite Pour lXObservation de la Terre-High Resolution Visible and High Resolution Visible Infra Red (SPOT-HRV and HRVIR) and Landsat-ETM+ can provide high spatial resolution images but revisiting period of 26 days for SPOT-HRV/ HRVIR and 16 days for Landsat-ETM+ is a major limitation as fire data require instantaneous acquisition plus the difficulty of mosaicing for regional and global studies. Also Landsat-ETM+ data are available free of charge but at present the cost of SPOT-HRV/ HRVIR prevents widespread usage of SPOT-HRV/HRVIR products especially in this part of the world where this study is being carried out. With the exception of MODIS all the above mentioned satellite sensors are not specifically aimed for fire detection as they do not have the robust spatial, temporal, spectral and radiometric properties for fire detection, therefore their accuracy in detecting fires are limited, therefore, MODIS dataset was used in this study.

\subsection{Moderate Resolution Imaging Spectroradiometer (MODIS)}

Moderate Resolution Imaging Spectroradiometer (MODIS) - instrument on board of Terra (morning) and Aqua (afternoon) spacecraft launched 1999 and 2002 respectively has provided a remarkable opportunity for monitoring fire activities both day and night (Justice, Giglio et al. 2002; Justice, Townshend et al. 2002; Giglio et al. 2006; Davies et al. 2009; Giglio et al. 2009). Furthermore, MODIS sensor includes bands that are specifically designed for fire detection at subpixel size. Unlike other satellite sensors, MODIS sensor on board the TERRA and AQUA were purposely designed for fire detection with enhanced fire algorithm that uses absolute and contextual approach to minimize false alarms by removing artifacts from the background, water bodies and cloud cover. Moreover the $4 \mu \mathrm{m}$ and $11 \mu \mathrm{m}$ saturate at $500 \mathrm{~K}$ and $400 \mathrm{~K}$ while 
the heritage AVHRR saturation point is 321 to $327 \mathrm{~K}$ (Ressl et al. 2009; Peterson et al. 2012). In addition to spectral capability of 36 bands, fire detection is possible with MODIS in three spatial resolutions: $250 \mathrm{~m}$ $(0.86 \mu \mathrm{m}), 500 \mathrm{~m}(2.1 \mu \mathrm{m}$ and $1.6 \mu \mathrm{m})$ and $1 \mathrm{~km}(4 \mu \mathrm{m}$ and $11 \mu \mathrm{m}$ ) encompassing a range of the electro magnetic spectrum from visible to thermal infrared region.

\section{Aim}

The aim of this study is to identify the magnitude of active fire in each type of the ecosystems in the study area using remotely sensed data derived from MODIS active fire product from January 2002 to December 2011 and examine the data obtained with Principal Component Analysis (PCA).

\section{Study area}

Ondo state which is the study area lies within latitudes $5^{\circ} 45^{\prime}$ and $7^{\circ} 52^{\prime} \mathrm{N}$ longitudes $4^{\circ} 20^{\prime}$ and $6^{\circ} 5^{\prime} \mathrm{E}$ in the south western part of Nigeria, covering an area of about $15,000 \mathrm{sq} \mathrm{km}$ in extent. The climate is largely controlled by south west monsoon and north east trade winds resulting in two distinct seasons of rainy (April to October) and dry season (November to March). The annual rainfall decreases from the south to the north with the annual range from $1150 \mathrm{~mm}$ to $2000 \mathrm{~mm}$ while the range of temperature is from $21^{\circ} \mathrm{C}$ to $29^{\circ} \mathrm{C}$ throughout the year. There is a network of numerous rivers, creeks and lakes in the State. Generally, the land rises from $7 \mathrm{~m}$ in the coastal plains to highlands and inselbergs of $350 \mathrm{~m}$ to the highest with $700 \mathrm{~m}$ above sea level in the northern parts of the State. The study area is endowed with natural vegetation, in the south there is high evergreen forest consisting varieties of hardwood timber such as Melicia excelsa, Antaris africana, Terminalia superba, Lophira procera, and Symphonia globulifera. Additionally, in the south there are freshwater swamp forests in the interior flat swamp along the rivers courses and mangrove vegetation near the coast. In the northern part, the vegetation consists of deciduous forest mixed with woody tree species such as Blighia sapida, Parkia biglobosa, and derived grasses called savanna. Agriculture is the mainstay of the economy with major crops like cacao, kolanuts, coffee, rubber, oil palm and citrus cultivated for export while crops like yam, cocoyam, rice, corn, cassava, vegetables and fruits are produced as food for local consumption. In most parts of the study area the natural vegetation has been cleared through large scale use of fire based on the bush fallow plot rotational system because hiring of tractors is very expensive and most times it is very difficult to get as such the original vegetation have been highly degraded by burning. It is important to note that some exotic trees like teak (Tectona grandis) and pulp wood (Gmelina arborea) were introduced to establish forest plantations for forest conservation. The ecosystem types are: Intensively cultivated farmlands, woodlands, highland forest, freshwater swamp forest, tree crop plantation, forest plantation, mangrove forest and forest reserves (Fig. 1 and Table 1).

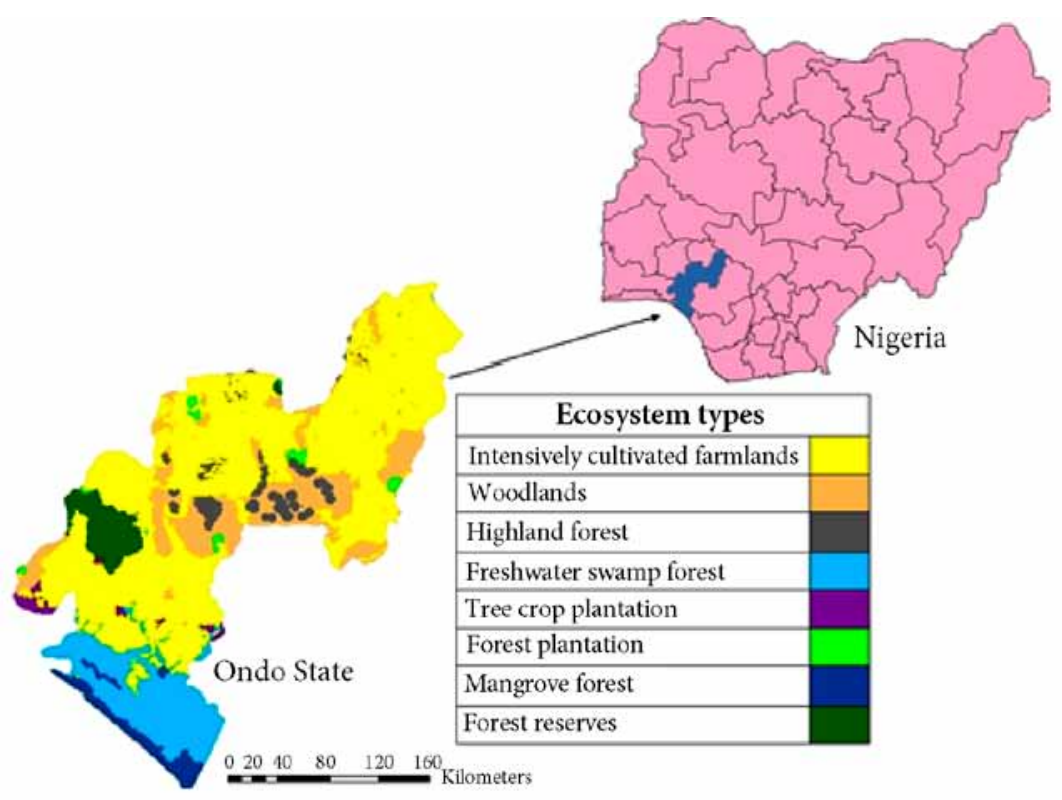

Fig. 1. Ecosystem type of the study area 
Table 1. Ecosystem type and their description

\begin{tabular}{|l|l|c|c|}
\hline \multicolumn{1}{|c|}{ Ecosystem Type } & \multicolumn{1}{|c|}{ Description } & $\begin{array}{c}\text { Actual size } \\
\text { (Sq. Km) }\end{array}$ & Percentage \\
\hline $\begin{array}{l}\text { Intensively cultivated } \\
\text { farmlands }\end{array}$ & $\begin{array}{l}\text { Arable farming near urban/rural settlements with crops like, } \\
\text { yams, cassava, corn, fruits and vegetables. }\end{array}$ & 8960.26 & 61.11 \\
\hline Woodlands & $\begin{array}{l}\text { Mainly deciduous trees with mixture of shrubs and tall } \\
\text { grasses that have developed as result of structural changes in } \\
\text { plant composition. }\end{array}$ & 2666.71 & 18.19 \\
\hline Highland forest & $\begin{array}{l}\text { Open forests on hill tops and dense forests along the slopes } \\
\text { with mosses and epiphytes. }\end{array}$ & 199.92 & 1.36 \\
\hline Freshwater swamp forest & $\begin{array}{l}\text { Forests in riparian zones along rivers and around lakes } \\
\text { including permanently/seasonally flooded wetlands. }\end{array}$ & 1885.28 & 12.86 \\
\hline Tree crop plantation & $\begin{array}{l}\text { Lands planted with permanent tree crops like cacao, kolanuts, } \\
\text { oil palm, coffee and rubber. }\end{array}$ & 153.03 & 1.04 \\
\hline Forest plantation & $\begin{array}{l}\text { Artificially established forest by vegetative planting/seedling } \\
\text { of trees like teak and pulp wood. }\end{array}$ & 66.65 & 0.45 \\
\hline Mangrove forest & Forests near the coast along intertidal flats and salt marshes. & 252.18 & 1.72 \\
\hline Forest reserves & $\begin{array}{l}\text { Forest with relatively little human disturbance and where } \\
\text { logging not allowed. }\end{array}$ & 478.91 & 3.27 \\
\hline Total & & 14662.94 & 100.00 \\
\hline
\end{tabular}

\section{Data collection and methodology}

Daily active fire data from the MODIS sensor on board of Terra and Aqua spacecrafts (morning - 10:30 AM and 10:30 PM afternoon - 1:30 PM and 1:30 AM equatorial overpass respectively) were downloaded from the MODIS Rapid Response System (MODIS 2015) from January 2002 to December 2011. The downloaded data were in shape and text file format. The shape file comprises of dots showing the hotspots of $1-\mathrm{km}$ MODIS active fire pixel and location as detected by MODIS sensor while the text file includes information on the type of sensor (Terra and Aqua), locations (latitude and longitude), confidence limit (0 to 100\%), acquisition time and date. The active fire hotspots from the MODIS datasets were imported into ArcGIS software version 9.3 for compilation into geographic information system (GIS) database management format. Satellite sensor data was superimposed on the map of ecosystem types (vector format) obtained from Ondo State Ministry of Natural Resources in Nigeria and the vector file of each ecosystem and was used to clip the dots (hot spots) showing fire detected within each ecosystem types. The dots were counted to obtain the fire statistics in the clipped subset of the ecosystem types: Intensively cultivated farmlands, woodlands, highland forest, freshwater swamp forest, tree crop plantation, forest plantation, mangrove forest and forest reserves. In order to avoid false fire alarm rates the reliability and confidence limits of the data acquired from MODIS active fire product were taken into consideration as the average confidence of limit for the study area was $66 \%$. A paired-samples t test was conducted to check for any significant difference in the fire datasets derived from the two satellites platforms of Terra and Aqua even though Terra and Aqua are expected to correlate since in general they observe the same fire on the same days. Paired-samples $t$ test shows a very good association between the two datasets (Terra and Aqua) with strong positive correlation between the two with $\mathrm{r}=0.86$ and the $\mathrm{p}$ value was $0.08>0.05$ at $95 \%$ confidence interval limit showing that there is no significant difference between the two datasets. Also MODIS active fire data was verified with fire data collected by the Ondo-State Government agencies in Nigeria, including the Ministry of Environment, Ministry of Natural Resources and Ministry of Agriculture; all the fire detected by MODIS active fire product were in agreement with the dates and time of fire occurrence of data collected by the above mentioned Government agencies. Subsequently, the fire statistics derived by counting the numbers of fire points (dots) clipped into each ecosystem polygons as detected by MODIS (TERRA and AQUA) satellite sensors for 120 months (January 2002 to December 2011) were used to investigate the annual trends of fire occurrence, geographical spread of fire activities and subjected to PCA to identify the important ecosystems zones of fire eruption zones. 


\subsection{Principal Component Analysis (PCA)}

Principal Component Analysis (PCA) is a multivariate statistical technique used for orthogonal transformation of original variables in a dataset into new set of variables through linear combinations of uncorrelated variables with the aim of reducing the dimensionality, minimizing redundancy and maximizing the variance of the original variables for easy interpretation of the importance of each variable in the dataset (Abdi, Williams 2010; Everitt, Hothorn 2011). PCA was used to extract data for the most important components purposely for a better understanding of the data structure while the relationships between combinations of the original variables (ecosystem types) and principal components was determined by component score coefficient matrix using multiple regression analysis and the highest principal component. For example, a random vector $X$ with correlated components $x_{i}\left(\mathrm{x}_{1}, \mathrm{x}_{2} \ldots\right.$ $\mathrm{x}_{8}$ ) was transform to a random vector $Y$ with uncorrelated components $y_{i}\left(\mathrm{y}_{1}, \mathrm{y}_{2} \ldots \mathrm{y}_{8}\right)$ in the varieties of ecosystems of the study area. In this study, we have a data matrix of $\mathrm{n}$ observations (Fire incidences for 120 months: January 2002 to December 2011) on p correlated variables ( 8 ecosystems: $\mathrm{x}_{1}, \mathrm{x}_{2} \ldots \mathrm{x}_{8}$ ). The correlated variable $\mathrm{p}$ in the original data (8 ecosystems) is expressed in the Equation 1 based on the assumption that the column vector ( $\mathrm{n}$ observations) is 0 :

$$
\mathrm{X}=\left[\begin{array}{l}
x 1 \\
\mathrm{x} 2 \\
\mathrm{x} 3 \\
\mathrm{x} 4 \\
\mathrm{x} 5 \\
\mathrm{x} 6 \\
\mathrm{x} 7 \\
\mathrm{x} 8
\end{array}\right] \sim\left[\begin{array}{l}
\text { Intensively cultivated farmlands } \\
\text { Woodlands } \\
\text { Highland forest } \\
\text { Forest Swamps } \\
\text { Tree crop plantation } \\
\text { Forest plantation } \\
\text { Mangrove } \\
\text { Forest reserve }
\end{array}\right] .
$$

Since the $\mathrm{X}$ original variable $\left(\mathrm{x}_{1}, \mathrm{x}_{2}, \ldots, \mathrm{x}_{8}\right)$ are measurements of the same units, a covariance matrix $(\mathrm{COV})$ of $\mathrm{X}$ was used and articulated as:

$$
\operatorname{COV}(\mathbf{X})=\left[\begin{array}{c}
\mathrm{x} 11 \mathrm{x} 12 \ldots \mathrm{x} 18 \\
\mathrm{x} 21 \mathrm{x} 22 \ldots \mathrm{x} 28 \\
\ldots \\
\ldots \\
\ldots \\
\mathrm{x} 81 \mathrm{x} 22 \ldots \mathrm{x} 88
\end{array}\right] .
$$

To identify principal components of $\mathrm{X}$, eigenvectors $\left(a_{11}, a_{12}, \ldots, a_{18)},\left(a_{21}, a_{22}, \ldots, a_{28}\right)\right.$ to $\left(a_{81}, a_{82}, \ldots, a_{88}\right)$ of $\operatorname{COV}(\mathrm{X})$ were used to transform $\mathrm{X}$ original variable to $\mathrm{Y}$ new variables $\mathrm{y}_{1}, \mathrm{y}_{2} \ldots \ldots . \mathrm{y}_{8}$ expressed as:

$$
\mathbf{Y} \sim\left[\begin{array}{c}
\mathrm{y} 1=\mathrm{a} 11 \mathrm{x} 1+\mathrm{a} 12 \times 2 \ldots \mathrm{a} 18 \times 8 \\
\mathrm{y} 2=\mathrm{a} 21 \mathrm{x} 1+\mathrm{a} 22 \times 2 \ldots \mathrm{a} 28 \mathrm{x} 8 \\
\ldots \\
\ldots \\
\ldots \\
y 8=\mathrm{a} 81 \mathrm{x} 1+\mathrm{a} 82 \times 2 \ldots \mathrm{a} 88 \mathrm{x} 8
\end{array}\right],
$$

where:

$\mathrm{y}_{1}, \mathrm{y}_{2}, \ldots, \mathrm{y}_{8}=$ Principal components;

$a_{11}, a_{12}, \ldots, a_{18}=$ First eigenvector of covariance matrix and coefficient of the first principal component;

$a_{21}, a_{22}, \ldots, a_{28}=$ Second eigenvector of covariance matrix and coefficient of the second principal component;

$a_{81}, a_{82}, \ldots, a_{88}=$ Eighth eigenvector of covariance matrix and coefficient of the eighth principal component;

$\mathrm{x}_{1}, \mathrm{x}_{2}, \ldots, \mathrm{x}_{8}=$ Original variables.

Eigenvectors $\mathrm{a}_{11}, \mathrm{a}_{12}, \ldots, \mathrm{a}_{18}$ maximize $\mathrm{y}_{1}$, equals to the first eigenvector of transformed $\mathrm{X}$ with the highest variance. The variance of each principal component is known as eigenvalue $(\lambda)$ of the associated eigenvector (a), so the direction of (a) in deriving new variables $\left(\mathrm{Y}=\mathrm{y}_{1}, \mathrm{y}_{2}, \ldots, \mathrm{y}_{8}\right)$ are the principal components obtained by means of eigenvectors (a) corresponding to the same eigenvalues $(\lambda)$ in any linear combination. Hence $y_{1}$ explains the highest variance (eigenvalue) of the original data and is the first principal component followed by $\mathrm{y}_{2}$ which is the second principal component uncorrelated with first principal component but have the second highest variance (eigenvalue) and so on in a decreasing order of importance and uncorrelated pattern with preceding principal component to the lowest variance $y 8$.

\subsection{Data screening for PCA}

Data screening was carried out to verify the compliance of the datasets used in this study with the requirements of PCA. These screening include sample adequacy criterion of Kaiser-Meyer-Olkin (KMO), Bartlett's test of sphericity and covariance matrix determinant. The value of KMO ranges from 0 to 1 and in this analysis the $\mathrm{KMO}$ is 0.88 which is near to 1 , indicating that the data samples are adequate and reliable. Bartlett's test was used to test the null hypothesis that the correlation matrix is an identical matrix, the test of significance shows that $\mathrm{p}<0.0001$ which is less than 
0.05 , hence, the null hypothesis was rejected implying that the correlation matrix is not an identical matrix but there are some relationships among the original variables making PCA suitable for this analysis. The covariance matrix determinant was 69.98; in this case it is high above 0.0001 signifying that there is no issue of singularity and multicollinearity in the data making it satisfactory for PCA to be used in this investigation. Covariance matrix was used in this PCA, because the measurements of the variables are in the same unit, obtained by counting the numbers of fire (dots) detected by MODIS in each polygon of the ecosystems, unlike the correlation matrix which is used to standardize data when measurements are of different units. Covariance matrix of the transformed data with eigenvalues greater than 1 and scree plot test of the eigenvalues related to each component was used to separate and retain the meaningful components while the unimportant ones were discarded, therefore, two out of the eight principal components were retained in this study.

\section{Data analysis}

\subsection{Annual trends and geographical distribution of fire occurrence}

The annual occurrence of fire shows an increasing pattern from the year 2002 to 2011 (10 years). In the year 2002 the annual fire observed was 39 while in the year 2011 it was 189 which is an increase of $384.6 \%$ and average of $38.46 \%$ annual increase (Fig. 2).

The annual mean of fire occurrence varies from 5 in 2002 to 24 in 2010 and 2011 while the standard deviation ranges from 6 in the year 2002 to 27 in the year 2010. The modal years were 2006 and 2007 with 136 fire incidences. The total annual fire incidences observed during the study period 10 years (120 months) was 1379 while the percentage contributed by each ecosystem ranges from the lowest value of $3.63 \%$ to highest value $49.67 \%$ for tree crop plantation to intensively cultivated farmlands respectively (Table 2).

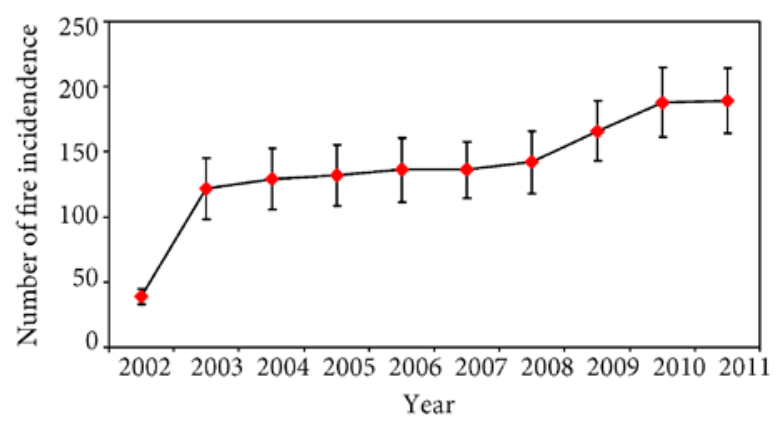

Fig. 2. Annual trend of fire incidence
The geographical distribution of fire events in the study area shows that intensively cultivated farmlands have the highest occurrence with the value of 685 fire events and the lowest was tree crop plantation with 50 while freshwater swamp forest have 250, highland forest 117 , woodland 104 , mangrove 61 , forest reserves 58 and forest plantation 54 (Table 2 and Fig. 3). The reason for the high fire occurrence in the freshwater swamp forest was as a result of petroleum mining activities in this ecosystem.

Table 2. Descriptive fire statistics for each ecosystem types (2002-2011)

\begin{tabular}{|c|c|c|c|c|}
\hline \multicolumn{5}{|c|}{ Descriptive Statistics } \\
\hline Ecosystems & $\begin{array}{c}\text { Fire } \\
\text { inci- } \\
\text { dences }\end{array}$ & Mean & $\begin{array}{l}\text { Percen- } \\
\text { tage }\end{array}$ & $\begin{array}{l}\text { Numbers of } \\
\text { months (Janua- } \\
\text { ry 2002-De- } \\
\text { cember 2011) }\end{array}$ \\
\hline $\begin{array}{l}\text { Intensive } \\
\text { cultivated } \\
\text { farmlands }\end{array}$ & 685 & 5.64 & 49.67 & 120 \\
\hline Woodlands & 104 & .85 & 7.54 & 120 \\
\hline $\begin{array}{l}\text { Highland } \\
\text { forest }\end{array}$ & 117 & 1.03 & 8.48 & 120 \\
\hline $\begin{array}{l}\text { Freshwater } \\
\text { swamp } \\
\text { forest }\end{array}$ & 250 & 2.01 & 18.13 & 120 \\
\hline $\begin{array}{l}\text { Tree crop } \\
\text { plantation }\end{array}$ & 50 & .42 & 3.63 & 120 \\
\hline $\begin{array}{l}\text { Forest } \\
\text { plantation }\end{array}$ & 54 & .45 & 3.92 & 120 \\
\hline $\begin{array}{l}\text { Mangrove } \\
\text { forest }\end{array}$ & 61 & .48 & 4.42 & 120 \\
\hline $\begin{array}{l}\text { Forest } \\
\text { reserves }\end{array}$ & 58 & .48 & 4.21 & 120 \\
\hline Total & 1379 & & 100 & \\
\hline
\end{tabular}

\subsection{Rotated component matrix}

Varimax rotation method was utilized to produce orthogonal transformation of the components along the principal axis for lucid interpretation of the two components extracted for this analysis. The contribution of the selected two principal components out of eight accounted for $92.29 \%$ of total variance in the data of which the first principal component contributed $87.56 \%$ while the second principal component contributes only $4.72 \%$. In this analysis and interpretation a measure of a variable that is loaded on a given component was determined by variables that have the value of 0.50 and above in the rotated component matrix and the loading of the variables in component (Table 3).

The first principal component has eigenvalue of 7.69. It explains $87.56 \%$ of the total variance in the data 
and it is heavily loaded on four variables: Highland forest $(0.92)$, forest plantation $(0.79)$, woodlands $(0.77)$ and intensively cultivated farmlands $(0.75)$. The loading for freshwater swamp forest was (0.45), tree crop plantation (0.46), mangrove $(-0.02)$, forest reserves (0.36) are low when compared with the bench mark of 0.50 including the negative value of -0.02 for mangrove. The second principal component has eigenvalue of 4.15. It explains $4.72 \%$ of the total variance in the data with three significant variables: Freshwater swamp forest $(0.63)$, forest reserve $(0.62)$ and tree crop plantation (0.52) while the second principal component

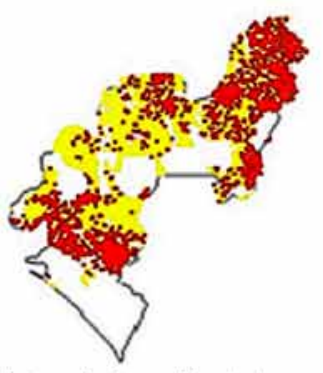

Intensively cultivated farm lands
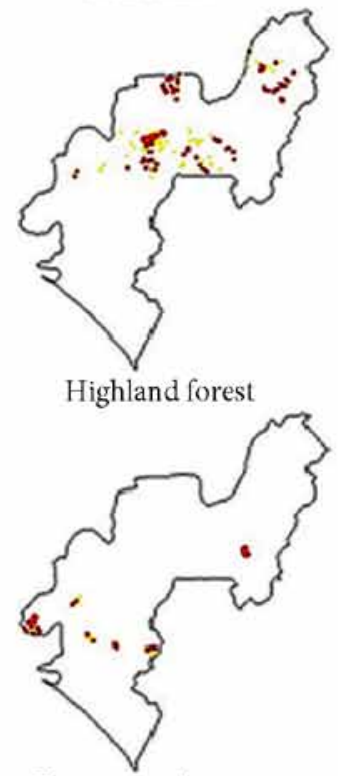

Tree crop plantation

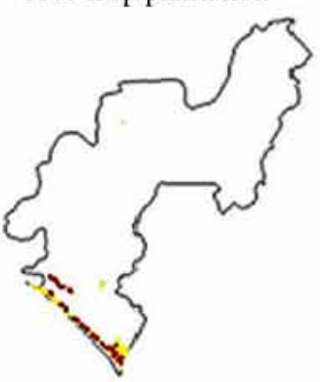

Mangrove forest
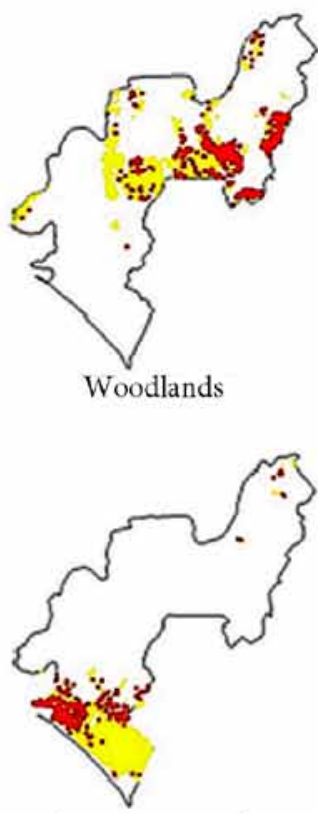

Freshwater swamp forest

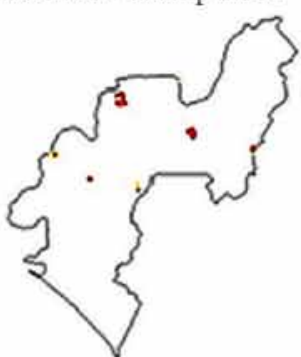

Forest plantation

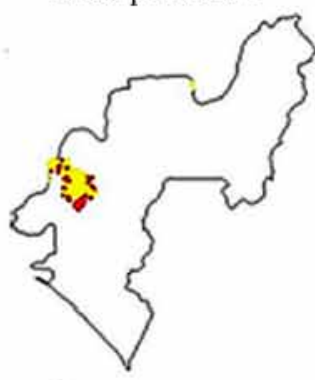

Forest reserves
Fig. 3. Geographical distribution of fire detected (red dots) in each of the ecosystem types (yellow polygon) from year 2002 to 2011 which include intensively cultivated farmlands (0.13), woodlands (0.46), highland forest (0.34), forest plantation (0.26), mangrove forest (0.19), are less significant variables, due to their low loading.

\subsection{Component score coefficient matrix}

In order to objectively identify the major zones of fire outbreak among the ecosystems component score coefficient matrix was used to determine the regression coefficient by relating the original variables to the first principal component contributed to the total variation in the data because of the high magnitude of $87.56 \%$ while the second principal component was considered to be insignificant and discarded because of low contribution of $4.72 \%$. The result shows that highland forest has the highest score with 0.65 followed by intensively cultivated farmlands 0.60 (Table 4).

Table 3. Rotated component matrix

\begin{tabular}{|l|c|c|}
\hline \multicolumn{3}{|c|}{ Rotated Component Matrix } \\
\hline \multirow{2}{*}{ Variables } & \multicolumn{2}{c|}{ Components } \\
\cline { 2 - 3 } & 1 & 2 \\
\hline Intensively cultivated farmlands & 0.75 & 0.13 \\
\hline Woodlands & 0.77 & 0.46 \\
\hline Highland forest & 0.92 & 0.34 \\
\hline Freshwater swamp forest & 0.45 & 0.63 \\
\hline Tree crop plantation & 0.46 & 0.52 \\
\hline Forest plantation & 0.79 & 0.26 \\
\hline Mangrove forest & -0.02 & 0.19 \\
\hline Forest reserve & 0.36 & 0.62 \\
\hline Eigenvalue & 7.69 & 4.15 \\
\hline Percentage of eigenvalue & 87.56 & 4.72 \\
\hline $\begin{array}{l}\text { Cumulative percentage of } \\
\text { eigenvalue }\end{array}$ & 87.56 & 92.29 \\
\hline
\end{tabular}

Table 4. Component Score Coefficient Matrix

\begin{tabular}{|l|c|}
\hline \multicolumn{2}{|c|}{ Component Score Coefficient Matrix } \\
\hline Variable & Component \\
\hline Intensive cultivated farmlands & 0.60 \\
\hline Woodlands & 0.21 \\
\hline Highland forest & 0.65 \\
\hline Freshwater swamp forest & -0.56 \\
\hline Tree crop plantation & -0.01 \\
\hline Forest plantation & 0.10 \\
\hline Mangrove & -0.07 \\
\hline Forest reserves & -0.07 \\
\hline
\end{tabular}


Others are with low scores: Woodlands (0.205), forest plantation (0.100) including negative scores for tree crop plantation $(-0.013)$, mangrove $(-0.069)$, forest reserves $(-0.065)$ all have low scores while freshwater swamp forest has the lowest value of -0.563 .

\section{Interpretation of results}

It is evident from this analysis that resultant fire events within the eight ecosystems studied are of two categories: Intentional fire use and accidental fires. The fire outburst in the variables that loaded heavily on the first principal component is as a result of intentional use of fire. These are highland forest, forest plantation, woodlands and intensive cultivated farmlands ecosystems. For example, fire is purposely used to gain accessibility into the highland forest and forest plantation for timber extraction while fire is mostly utilized for clearing of land clearing in preparation planting of crops.

The variables that loaded heavily on second principal component is primarily accidental fire. These are fire incidence in freshwater swamp forest, forest reserves and tree crop plantation. Freshwater swamp forest for example, has a total of 250 fires events and accounted for $18.13 \%$ during the study period which is abnormal for this type of ecosystem in an aquatic environment. However this unusual fire episode is as a result of oil spill and leakages of petroleum pipelines because major petroleum and gas exploitation are located within this ecosystem in the study area. Forest reserves are protected areas while tree crop plantations are agricultural lands with permanent tree crops where fire incidences are rare.

The result of the component score coefficient matrix shows that highland forest has the highest score of 0.65 followed by intensively cultivated farmlands with 0.60 . Highland forest and intensively cultivated farmlands ecosystem are therefore the hub fire outbreak identified among the ecosystems.

\section{Conclusions}

The MODIS active fire product has been a valuable data source for detecting fire hotspots and PCA satisfactorily identified the major zones and causes of fire occurrence in this study. This was corroborated with the information gathered by the environmental, agricultural and forestry resources related Government agencies in Ondo State of Nigeria. It is found that descriptive statistics obtained from MODIS shows that intensively cultivated farmlands has the highest fire events of 685 followed by freshwater swamp forest with 250 occurrences due to frequent accidental fires from petroleum production. Highland forest, forest plantation, woodlands and intensive cultivated farmlands ecosystems are heavily loaded on the first principal component originating from intentional fire use while second principal component are heavily loaded with freshwater swamp forest, forest reserves and tree crop plantation emanating from accidental fires. The regression coefficient of component score matrix revealed that highland forest and intensively cultivated farmlands are the major ecosystem centres of fire occurrence in this study whereas from the entire analysis fire incidence in the mangrove forest is still very remote.

Major fire prevention efforts therefore should be concentrated on intensively cultivated farmlands, highland forest and in particular fire from freshwater swamp forest where petroleum production is rampant. There is need to educate and create awareness about the environmental impact and hazard of fire for farmers and lumbers in particular and all inhabitant in general on ecosystem burning while law enforcement is urgently required on indiscriminate use of fire (including mitigation) and safety measures to be established by petroleum producing companies.

Finally, the results of this study will provide a lead to a well coordinated near real time information that can be of utility for early warning, monitoring, mitigation and intervention against catastrophic active fire disaster plus a supportive guide for post fire assessment and recovery over geographical regions that have similar ecosystems and human activities with the study area.

\section{References}

Abdi, H.; Williams L. J. 2010. Principal component analysis, Wiley Interdisciplinary Reviews: Computational Statistics 2(4): 433-459. http://dx.doi.org/10.1002/wics.101

Alves, C. 1.; Vicente, A.; Nunes, T.; Gonçalves, C.; Fernandes, A. P.; Mirante, F.; Tarelho, L.; Sánchez de la Campa, A. M.; Querol, X.; Caseiro, A.; Monteiro, C.; Evtyugina, M.; Pio, C. 2011. Summer 2009 wildfires in Portugal: Emission of trace gases and aerosol composition, Atmospheric Environment 45(3): 641-649. http://dx.doi.org/10.1016/j.atmosenv.2010.10.031

Amraoui, M.; DaCamara, C. C. Pereira, J. M. C. 2010. Detection and monitoring of African vegetation fires using MSGSEVIRI imagery, Remote Sensing of Environment 114(5): 1038-1052. http://dx.doi.org/10.1016/j.rse.2009.12.019

Andersson, M.; Michelsen, A.; Jensen, M.; Kjøller, A.2010. Tropical savannah woodland: effects of experimental fire on soil microorganisms and soil emissions of carbon dioxide, Soil Biology and Biochemistry 36(5): 849-858. http://dx.doi.org/10.1016/j.soilbio.2004.01.015 
Arneth, A.; Harrison, S. P.; Zaehle, S.; Tsigaridis, K.; Menon, S.; Bartlein, P. J.; Feichter, J.; Korhola, A.; Kulmala, M.; O’Donnell, D.; Schurgers, G.; Sorvari, S.; Vesala, T. 2004. Terrestrial biogeochemical feedbacks in the climate system, Nature Geoscience 3(8): 525-532.

http://dx.doi.org/10.1038/ngeo905

Arroyo, L. A.; Pascual, C.; Manzanera, J. A. 2008. Fire models and methods to map fuel types: The role of remote sensing, Forest Ecology and Management 256(6): 1239-1252. http://dx.doi.org/10.1016/j.foreco.2008.06.048

Bartalev, S., Egorov, V.; Loupian, E.; Uvarov I. 2007. Multi-year circumpolar assessment of the area burnt in boreal ecosystems using SPOT-VEGETATION, International Journal of Remote Sensing 28(6): 1397-1404. http://dx.doi.org/10.1080/01431160600840978

Bowman, D. M., Balch, J. K.; Artaxo, J. K. P.; Bond, W. J.; Carlson, J. M.; Cochrane, M. A.; D’Antonio, C. M.; DeFries, R. S.; Doyle, J. C.; Harrison, S. P.; Johnston, F. H.; Keeley, J. E.; Krawchuk, M. A. Kull, C. A.; Marston, J. B.; Moritz, M. A.; Prentice, I.; Roos, C. I. Scott, A. C.; Swetnam, T.W. van der Werf, G. R.; Pyne S. J. 2009. Fire in the Earth system, Science 324(5926): 481-484.

http://dx.doi.org/10.1126/science.1163886

Changnon, S. A.; Holton J. R. 2003. Weather modification |Inadvertant. Encyclopedia of Atmospheric Sciences. Oxford: Academic Press, 2533-2537. http://dx.doi.org/10.1016/B0-12-227090-8/00454-1

Chuvieco, E.; Aguado, I.; Yebra, M.; Nieto, H.; Salas, J.; Martín, M. P.; Vilar, L.; Martínez, J.; Martín, S.; Ibarra, P.; de la Riva, J.; Baeza, J.; Rodríguez, F.; Molina, J. R.; Herrera, M. A.; Zamora, R. 2010. Development of a framework for fire risk assessment using remote sensing and geographic information system technologies, Ecological Modelling 221(1): 4658. http://dx.doi.org/10.1016/j.ecolmodel.2008.11.017

d'Oliveira, M. V. N.; Alvarado, E. C.; Santos, J. C.; Carvalho Jr., J. A. 2011. Forest natural regeneration and biomass production after slash and burn in a seasonally dry forest in the Southern Brazilian Amazon, Forest Ecology and Management 261(9): 1490-1498.

http://dx.doi.org/10.1016/j.foreco.2011.01.014

Davies, D. K.; Ilavajhala, S.; Wong, M. M.; Justice, C. O. 2009. Fire information for resource management system: archiving and distributing MODIS active fire data, Geoscience and Remote Sensing, IEEE Transactions 47(1): 72-79.

Devineau, J-L.; Fournier, A. A.; Nignan, S. 2010. Savanna fire regimes assessment with MODIS fire data: Their relationship to land cover and plant species distribution in western Burkina Faso (West Africa), Journal of Arid Environments 74(9): 1092-1101.

http://dx.doi.org/10.1016/j.jaridenv.2010.03.009

Dlamini, W. M. 2009. Characterization of the July 2007 Swaziland fire disaster using satellite remote sensing and GIS. Applied Geography 29(3): 299-307.

http://dx.doi.org/10.1016/j.apgeog.2008.10.007

Everitt, B.; Hothorn, T. 2011. Principal components analysis. An Introduction to Applied Multivariate Analysis with R. Springer, 61-103. http://dx.doi.org/10.1007/978-1-4419-9650-3_3

Flasse, S.; Ceccato, P. 1996. A contextual algorithm for AVHRR fire detection, International Journal of Remote Sensing 17(2): 419-424. http://dx.doi.org/10.1080/01431169608949018

Freitas, S. R.; Longo, K. M.; Silva Dias, M. A. F.; Silva Dias, P. L.; Chatfield, R.; Prins, E.; Artaxo, P.; Grell, G. A.; Recuero, F. S.
2005. Monitoring the transport of biomass burning emissions in South America, Environmental Fluid Mechanics 5(1): 135-167. http://dx.doi.org/10.1007/s10652-005-0243-7

Fuller, D. O.; Murphy, K. 2006. The ENSO-fire dynamic in insular Southeast Asia, Climatic Change 74(4): 435-455. http://dx.doi.org/10.1007/s10584-006-0432-5

Giglio, L.; Csiszar, I.; Restás, Á.; Morisette, J. T.; Schroeder, W.; Morton, D.; Justice, C. O. 2008. Active fire detection and characterization with the advanced spaceborne thermal emission and reflection radiometer (ASTER), Remote Sensing of Environment 112(6): 3055-3063.

http://dx.doi.org/10.1016/j.rse.2008.03.003

Giglio, L.; Csiszar, I.; Justice, C. O. 2006. Global distribution and seasonality of active fires as observed with the terra and aqua moderate resolution imaging spectroradiometer (MODIS) sensors, Journal of Geophysical Research 111(G2): G02016. http://dx.doi.org/10.1029/2005JG000142

Giglio, L.; Descloitres, J.; Justice, C. O.; Kaufman, Y. J. 2003. An enhanced contextual fire detection algorithm for MODIS, Remote Sensing of Environment 87(2): 273-282. http://dx.doi.org/10.1016/S0034-4257(03)00184-6

Giglio, L.; Loboda, T.; Roy, D. P.; Quayle, B.; Justice, C. O. 2009. An active-fire based burned area mapping algorithm for the MODIS sensor, Remote Sensing of Environment 113(2): 408-420. http://dx.doi.org/10.1016/j.rse.2008.10.006

Haywood, J.; Pelon, J.; Formenti, P.; Bharmal, N.; Brooks, M.; Capes, G.; Chazette, P.; Chou, C.; Christopher, S.; Coe, H.; Cuesta, J.; Derimian, Y.; Desboeufs, K.; Greed, G.; Harrison, M.; Heese, B.; Highwood, E. J.; Johnson, B.; Mallet, M.; Marticorena, B.; Marsham, J.; Milton, S.; Myhre, G.; Osborne, S. R.; Parker, D. J.; Rajot, J.-L.; Schulz, M.; Slingo, A.; Tanre', D.; Tulet, P. 2008. Overview of the dust and biomass-burning experiment and African monsoon multidisciplinary analysis special observing period-0, Journal of Geophysical Research: Atmospheres 113(D23). http://dx.doi.org/10.1029/2008JD010077

He, L.; Li, Z. 2012. Enhancement of a fire detection algorithm by eliminating solar reflection in the mid-IR band: application to AVHRR data, International Journal of Remote Sensing 33(22): 7047-7059.

http://dx.doi.org/10.1080/2150704X.2012.699202

Jury, M. R.; Whitehall, K. 2010. Warming of an elevated layer over Africa, Climatic Change 99(1-2): 229-245. http://dx.doi.org/10.1007/s10584-009-9657-4

Justice, C. O.; Townshend, J.; Vermote, E. F.; Masuoka, E.; Wolfe, R. F.; Saleous, N.; Roy, D. P.; Morisette, J. T. 2002. An overview of MODIS Land data processing and product status, Remote Sensing of Environment 83(1): 3-15. http://dx.doi.org/10.1016/S0034-4257(02)00084-6

Justice, C. O.; Giglio, L.; Korontzi, S.; Owens, J.; Morisette, J. T.; Roy, D.; Descloitres, J.; Alleaume, S.; Petitcolin, F.; Kaufman Y. 2002. The MODIS fire products, Remote Sensing of Environment 83(1): 244-262. http://dx.doi.org/10.1016/S0034-4257(02)00076-7

Justice, C. O.; Kendall, J. D.; Dowty, P. R.; Scholes, R. J. 1996. Satellite remote sensing of fires during the SAFARI campaign using NOAA advanced very high resolution radiometer data, Journal of Geophysical Research: Atmospheres (1984-2012) 101(D19): 23851-23863.

Keeley, J. E. 2009. Fire intensity, fire severity and burn severity: a brief review and suggested usage, International Journal of Wildland Fire 18(1): 116-126. http://dx.doi.org/10.1071/WF07049 
Kiran Chand, T. R.; Badarinath, K. V. S.; Prasad, V. K.; Murthy, M. S. R.; Elvidge, C. S. D.; Tuttle, T. 2006. Monitoring forest fires over the Indian region using Defense Meteorological Satellite Program-Operational Linescan System nighttime satellite data, Remote Sensing of Environment 103(2): 165-178. http://dx.doi.org/10.1016/j.rse.2006.03.010

Langmann, B.; Duncan, B.; Textor, C.; Trentmann, J.; van der Werf, G. R. 2009. Vegetation fire emissions and their impact on air pollution and climate, Atmospheric Environment 43(1): 107-116. http://dx.doi.org/10.1016/j.atmosenv.2008.09.047

Lentile, L. B.; Holden, Z. A.; Smith, A. M. S.; Falkowski, M. I. J.; Hudak, A. T.; Morgan, P.; Lewis, S. A.; Gessler, P. E.; Benson, N. C. 2006. Remote sensing techniques to assess active fire characteristics and post-fire effects International Journal of Wildland Fire 15(3): 319-345. http://dx.doi.org/10.1071/WF05097

MODIS Rapid Response System [online], [cited February 5 2015]. Available from Internet: http://earthdata.nasa.gov/ data/near-real-time-data/firms

Montiel, C.; Kraus, D. T. 2010. Best practices of fire use: prescribed burning and suppression: Fire programmes in selected case-study regions in Europe. European Forest Institute.

Mota, J. B. W.; Pereira, J. M. C.; Oom, D.; Vasconcelos, M. J. P.; Schultz, M. 2006. Screening the ESA ATSR-2 World Fire Atlas (1997-2002), Atmospheric Chemistry and Physics 6(5): 1409-1424. http://dx.doi.org/10.5194/acp-6-1409-2006

Peterson, D.; Wang, J.; Ichoku, C.; Hyer, E.; Ambrosia V. 2013. A sub-pixel-based calculation of fire radiative power from MODIS observations: 1: Algorithm development and initial assessment, Remote Sensing of Environment 108(15): 262279. http://dx.doi.org/10.1016/j.rse.2012.10.036

Pu, R.; Li, Z.; Gong, P.; Csiszar, I.; Fraser, R.; Hao, W.; Kondragunta, S.; Weng, F. 2007. Development and analysis of a 12-year daily 1-km forest fire dataset across North America from NOAA/AVHRR data, Remote Sensing of Environment 108(2): 198-208. http://dx.doi.org/10.1016/j.rse.2006.02.027

Raish, C.; González-Cabán, A.; Condie, C. J. 2005. The importance of traditional fire use and management practices for contemporary land managers in the American Southwest, Global Environmental Change Part B: Environmental Hazards 6(2): 115-122.

http://dx.doi.org/10.1016/j.hazards.2005.10.004

Ramanathan, V.; Feng, Y. 2009. Air pollution, greenhouse gases and climate change: Global and regional perspectives, Atmospheric Environment 43(1): 37-50. http://dx.doi.org/10.1016/j.atmosenv.2008.09.063

Reid, J. S.; Hyer, E. J.; Prins, E. M.; Westphal, D. L.; Jianglong, Z.; Jun, W.; Christopher, S. A.; Curtis, C. A.; Schmidt, C. C.; Eleuterio, D. P.; Richardson, K. A.; Hoffman, J. P. 2009. Global monitoring and forecasting of biomass-burning smoke: Description of and lessons from the Fire Locating and Modeling of Burning Emissions (FLAMBE) program, Selected Topics in Applied Earth Observations and Remote Sensing, IEEE Journal of 2(3): 144-162.
Ressl, R.; Lopez, G.; Cruz, I.; Colditz, R. R.; Schmidt, M.; Ressl, S.; Jiménez, R. 2009. Operational active fire mapping and burnt area identification applicable to Mexican Nature Protection Areas using MODIS and NOAA-AVHRR direct readout data, Remote Sensing of Environment 113(6): 11131126. http://dx.doi.org/10.1016/j.rse.2008.10.016

Roberts, G. J.; Wooster M. J. 2008. Fire detection and fire characterization over Africa using Meteosat SEVIRI, Geoscience and Remote Sensing, IEEE Transactions 46(4): 1200-1218.

Silva, J.; Sá, A. C. L.; Pereira, J. M. C. 2005. Comparison of burned area estimates derived from SPOT-VEGETATION and Landsat ETM+ data in Africa: Influence of spatial pattern and vegetation type, Remote Sensing of Environment 96(2): 188-201. http://dx.doi.org/10.1016/j.rse.2005.02.004

Van Der Werf, G. R.; Randerson, J. T.; Giglio, L.; Collatz, G. J.; Kasibhatla, P. S.; Arellano, A. F. 2006. Interannual variability of global biomass burning emissions from 1997 to 2004, Atmospheric Chemistry and Physics Discussions 6(2): 31753226. http://dx.doi.org/10.5194/acpd-6-3175-2006

Xu, W.; Wooster, M. J.; Roberts, G.; Freeborn P. 2010. New GOES imager algorithms for cloud and active fire detection and fire radiative power assessment across North, South and Central America, Remote Sensing of Environment 114(9): 1876-1895. http://dx.doi.org/10.1016/j.rse.2010.03.012

Zhang, S.; Penner, J. E.; Torres, O. 2005. Inverse modeling of biomass burning emissions using Total Ozone Mapping Spectrometer aerosol index for 1997, Journal of Geophysical Research 110(D21): D21306.

http://dx.doi.org/10.1029/2004JD005738

Zhang, X.; Kondragunta, S. 2008. Temporal and spatial variability in biomass burned areas across the USA derived from the GOES fire product, Remote Sensing of Environment 112(6): 2886-2897. http://dx.doi.org/10.1016/j.rse.2008.02.006

Zhang, Z. M.; Machin, G. 2009. Overview of radiation thermometry, Experimental Methods in the Physical Sciences 42: $1-28$.

Zhao, T. X.-P.; Ackerman, S.; Guo. W. 2010. Dust and smoke detection for multi-channel imagers, Remote Sensing 2(10): 2347-2368. http://dx.doi.org/10.3390/rs2102347

Ebenezer Yemi OGUNBADEWA, PhD, is presently a Reader / Associate Professor in remote sensing and geographical information systems at Adekunle Ajasin University, Akungba Ondo-State, Nigeria. His research interest includes environmental and climate change modelling with emphasis on satellite remote sensing and geographical information systems applications. $\mathrm{He}$ is a member of Remote sensing and Photogrammetry Society (RSPSoc) of the United Kingdom, American Geophysical Union (AGU) and American Society for Photogrammetry and Remote Sensing (ASPRS). 